\title{
ANALISIS DAN PERANCANGAN OPERASIONAL SISTEM BERBASISKAN CRM \\ (STUDI KASUS PADA PT TERANG DUNIA INTERNUSA)
}

\author{
Tanty Oktavia \\ Jurusan Sistem Informasi, Fakultas Ilmu Komputer, Universitas Bina Nusantara, \\ Jln. K.H. Syahdan No. 9, Kemanggisan/Palmerah, Jakarta Barat 11480 \\ tanty_oktavia@yahoo.com
}

\begin{abstract}
Article to design an operational system based Customer Relationship Management (CRM) that can connect customers with the company. It is expected that the exchange of information between both parties can be properly channeled, in short, accurate, and actual business-process occurs. Information is an important part in the business cycle because it includes all the transactions that are closely related business activities that occurred. The method used in designing this system is the Object Oriented Analysis and Design. Results to be achieved from this research are the formation of a web-based system that is able to become a liaison between the customer and the company, so the relationship can be well maintained. Customer satisfaction towards services obtained during the conduct of business transactions will have a positive impact for the company, as this can make the customers stay loyal to the company, as well as company profit can be increased as increasing customer loyalty.
\end{abstract}

Keywords: Customer, Customer Relationship Management, Loyalty

\begin{abstract}
ABSTRAK
Analisis dan perancangan yang dilakukan bertujuan untuk merancang suatu operasional sistem berbasiskan Customer Relationship Management (CRM) yang dapat menghubungkan pelanggan dengan perusahaan. Hal ini bertujuan agar pertukaran informasi antar kedua belah pihak dapat tersalurkan dengan baik, dalam kurun waktu singkat, akurat, dan aktual selama proses bisnis terjadi. Informasi merupakan bagian penting dalam siklus transaksi karena memuat segala hal yang berkaitan erat dengan kegiatan bisnis yang terjadi. Metode yang digunakan dalam perancangan sistem ini adalah Object Oriented Analysis and Design. Hasil yang ingin dicapai dari penelitian ini adalah terbentuknya suatu sistem berbasiskan web yang mampu menjadi penghubung antara pelanggan dengan perusahaan, sehingga relasi dapat terjalin dengan baik. Kepuasan pelanggan terhadap pelayanan yang diperoleh selama melakukan transaksi bisnis akan berdampak positif bagi perusahaan, karena hal ini dapat membuat pelanggan tetap setia terhadap perusahaan, sekaligus profit perusahaan dapat semakin bertambah seiring dengan meningkatnya loyalitas pelanggan.
\end{abstract}

Kata kunci: Pelanggan, CRM, Loyalitas 


\section{PENDAHULUAN}

Strategi bisnis yang saat ini banyak dikembangkan perusahaan dalam rangka menjalin hubungan dengan para pelanggan adalah Customer Relationship Management atau yang sering disebut dengan CRM. CRM merupakan suatu strategi aplikasi bisnis yang dirancang guna mempertahankan loyalitas dan kepercayaan para pelanggan terhadap produk maupun jasa yang ditawarkan oleh perusahaan, sehingga diharapkan dapat meningkatkan profit bagi perusahaan. Selain itu dengan sistem CRM, relasi hubungan antara perusahaan dengan pelanggan dapat tetap terjaga dan terjalin dengan baik. Seluruh informasi baru yang dikeluarkan perusahaan dapat dengan cepat disampaikan kepada para pelanggan tanpa terbatas ruang dan waktu. Pengembangan aplikasi CRM bisa sangat bervariasi, tergantung dari pendekatan pasar, strategi bisnis, serta fitur-fitur yang ditawarkan sebagai nilai tambah bagi daya saing suatu bisnis. Suatu aplikasi CRM haruslah dapat berperan secara multifungsi yaitu dalam hal pemasaran, perdagangan, dan pelayanan.

PT Terang Dunia Internusa sebagai suatu perusahaan yang berlokasi di daerah Jakarta termasuk salah satu perusahaan yang berorientasi pada pelanggan. Perusahaan ini bergerak dalam bidang produksi dan distribusi sepeda dan sparepart sepeda yang bermerek United. Perusahaan ini memiliki beberapa anak cabang perusahaan yang semuanya tersebar di beberapa daerah, diantaranya Jakarta, Bogor, Bandung, Yogyakarta, Palembang, dan daerah sekitarnya. Sejak awal berdirinya, perusahaan ini telah menetapkan orientasi proses bisnisnya berdasarkan kebutuhan para pelanggan. Hal ini dapat dibuktikan dengan telah dipercayanya produk ini di kalangan masyarakat. Perusahaan terus-menerus melakukan inovasi produk, bahkan baru-baru ini perusahaan meluncurkan suatu jenis sepeda yang bersifat personal, dimana sepeda tersebut dapat disesuaikan dengan ukuran pengendaranya. Mulai dari segi tempat duduk, ketinggian dari sepeda, sampai panjang dari sepedanya disesuaikan dengan ukuran badan pengendara sepedanya. Hal ini dilakukan perusahaan dengan tujuan agar pelanggan dapat nyaman mengendarai sepeda ini. Selain itu, PT Terang Dunia Internusa juga menyediakan layanan purnajual, dimana apabila terjadi kerusakan pada sparepart ataupun sepeda yang dibeli selama jangka waktu satu tahun dari tanggal pembelian, maka PT Terang Dunia Internusa akan menanggung segala kerusakan tersebut dengan memberikan pelayanan pada produk yang rusak. Hal ini merupakan suatu bentuk pelayanan yang diberikan perusahaan guna memberikan kepuasan bagi para pelanggannya. Fokusnya perusahaan terhadap pelayanan pelanggan, membuat perusahaan memutuskan mengintegrasikan konsep CRM dalam proses bisnisnya. Sehingga diharapkan orientasi perusahaan terhadap kepuasan pelanggan dapat tersalur melalui penerapan sistem CRM ini.

Konsep dasar CRM diawali dengan mengenal, mengetahui, dan menggali apa yang dibutuhkan dan diharapkan pelanggan dari perusahaan dengan menggunakan media elektronik. Dengan begitu, perusahaan dapat lebih mudah mewujudkan apa yang dibutuhkan dan apa yang diharapkan oleh pelanggan-nya. Untuk mengenal atau mengetahui apa yang dibutuhkan, perusahaan harus memiliki catatan tentang para pelanggannya. Misalnya, selain informasi tentang produk yang dimiliki beserta produk record-nya, bisa digali juga informasi lainnya seperti pekerjaan, posisi di perusahaan di mana mereka bekerja, hobi, makanan favorit, jenis film yang disukai, dll. Ini sangat bermanfaat. Misalnya jika mereka kebetulan datang ke perusahaan, maka sentuhan personal dapat dilakukan. Ini dapat memberikan efek yang menyenangkan bagi pelanggan. Informasi di atas juga dipergunakan perusahaan untuk membangun relasi, tidak hanya relasi antara perusahaan dengan pelanggannya, tetapi juga bisa memperkuat relasi itu dengan membangun relasi antara pelanggan dengan pelanggan lainnya, yang mengarah bagi keuntungan perusahaan.

Hal ini menjadi sangat menarik, karena fokus pelanggan datang ke perusahaan tidak lagi hanya karena mereka membutuhkan barang saja, tetapi karena merasa dirinya memiliki relasi yang kuat dengan perusahaan dan dengan rekan-rekannya yang juga menjadi pelanggan perusahaan itu. Dengan demikian sedikit demi sedikit loyalitas kepada perusahaan juga ikut terbangun, sehingga pada 
akhirnya mereka akan merasa terpuaskan oleh perusahaan. Jika sudah demikian harga bukan lagi sebagai faktor yang menentukan, tetapi menjadi sesuatu yang relatif bagi pelanggan yang telah merasakan relasi ini.

Pada sistem CRM, proses bisnis yang berlangsung dalam suatu perusahaan difokuskan kepada pelanggan. Menurut Kincaid (2003: 4), terdapat model pengaturan nilai yang dapat dilakukan perusahaan dalam menjaga hubungan dengan pelanggan, diantaranya adalah Operational Excellence, meliputi membangun proses bisnis yang menyediakan produk dengan kualitas yang terbaik, penawaran harga yang terbaik, dan proses transaksi pembelian yang terbaik pula, sehingga dapat menguntungkan pihak pelanggan; Product Leadership, meliputi memfokuskan investasi dan kekuatan dalam mengembangkan produk yang terbaru atau revolusi penelitian produk yang baru, sehingga produk yang ditawarkan merupakan produk yang terbaik bagi pelanggan; Relasi dengan pelanggan meliputi membangun hubungan yang erat dengan pelanggan, dengan mencari tahu hal-hal yang berkaitan dengan pelanggan, sehingga dapat memberikan pelayanan yang terbaik bagi pelanggan.

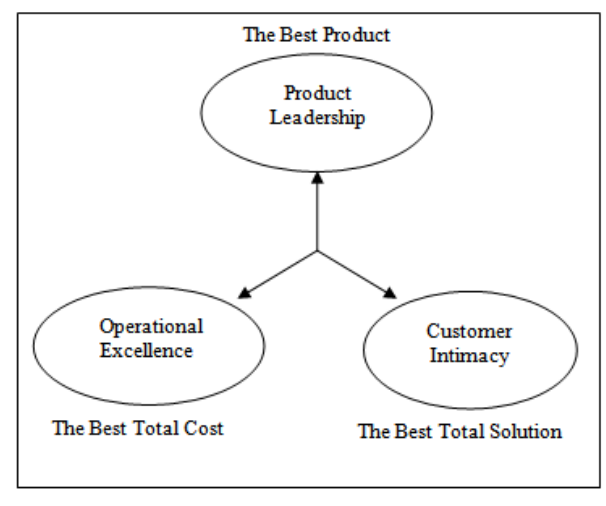

Gambar 1 Model Pengaturan Nilai Sumber Kincaid (2003: 4)

Menurut Kalakota dan Robinson (2001: 178-179), Arsitektur CRM yang saat ini berlaku berbeda dengan arsitektur CRM yang lama, dimana pada arsitektur yang baru perusahaan mengorganisasikan proses bisnis berdasarkan kebutuhan pelanggan dan bukan pada fungsi internal perusahaan, seperti marketing dan penjualan. Umpan balik dari pelanggan menjadi bagian integral dari proses untuk meningkatkan proses CRM ini yang memungkinkan proses CRM beradaptasi dengan kebutuhan pelanggan. Dengan kata lain, tindakan yang dilakukan oleh perusahaan diprioritaskan pada tujuan perusahaan secara keseluruhan untuk menciptakan kepuasaan pelanggan dan bukan diprioritaskan pada unit fungsional perusahaan.

The Best Total Solution

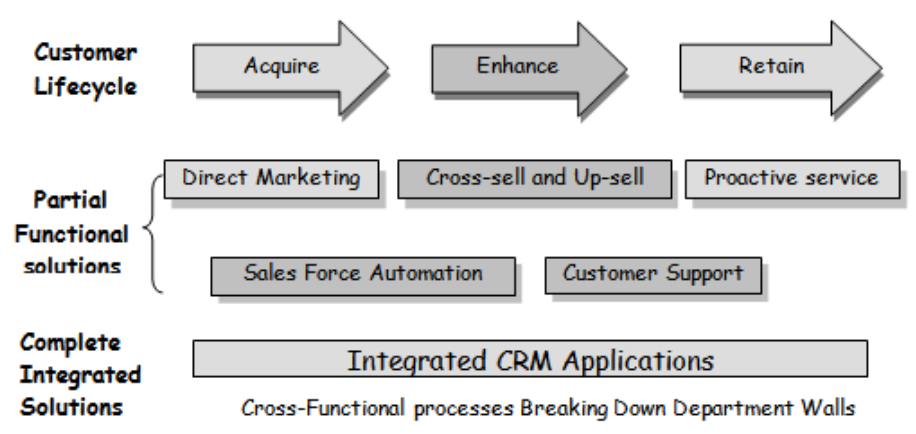

Gambar 2 Arsitektur CRM

Sumber: Kalakota dan Robinson, (2001: 179) 
Dipandang dari sisi obyektifnya, yaitu untuk meningkatkan kualitas hubungan antara perusahaan dengan pelanggan agar pelanggan dapat menjadi pelanggan yang setia dan loyal terhadap perusahaan, maka aplikasi CRM tidak membedakan apakah perusahaan tersebut berskala kecil, menengah, atau besar. Menurut Seybold (2002 : 6), jenis aplikasi CRM dapat dibagi menjadi 3 kategori, yaitu: Operational CRM, Analytical CRM, dan Collaborative CRM

\section{Operational CRM}

Bertujuan memberikan pengalaman pada pelanggan yang akhirnya akan memberikan value lebih pada pelanggan, dan pelanggan yang merasa puas akan menimbulkan kesetiaan pelanggan. Aplikasi operational CRM ini dibagi menjadi dua jenis, yaitu Customer-Touching Systems dan Customer-Facing Systems

\section{Customer-Touching Systems}

Fokus dari customer-touching systems ini adalah campaign management, e-Commerce dan self service customer support. Pelanggan dapat berinteraksi langsung dengan aplikasi-aplikasi yang disediakan oleh perusahaan, seperti: Campaign management, merupakan penawaran secara otomatis. Perusahaan menawarkan produk baik pada calon pelanggan ataupun pelanggan itu sendiri bedasarkan kebutuhan, jadwal, atau spesifikasi lainnya; Electronic commerce, penerapan fungsi-fungsi sebuah perusahaan seperti pemasaran, penjualan, dan layanan melalui online touchpoint, umumnya adalah web. Aplikasi ini memungkinkan penjual memasarkan produk melalui katalog online sesuai bidang bisnis yang dijalankan. Pelanggan dapat berbelanja melalui keranjang belanja yang virtual dan membeli produk secara virtual. Penjual juga bisa menjalankan self-service support task seperti status pemesanan dan proses pengembalian; Self-service customer support, teknologi ini memungkinkan pelanggan mendapatkan informasi yang mereka butuhkan melalui diri sendiri. Informasi dan layanan teknologi ini berupa pendukung produk, permintaan layanan, mengelola informasi mengenai mereka dan mengelola pemesanan mereka.

\section{Customer-Facing Systems}

Realisasi sistem ini dapat berupa contact center, sales force automation, dan field service. Disebut dengan customer-facing karena mewakili penjualan, layanan lapangan, dan contact center yang berinteraksi dengan pelanggan. Contact center merupakan aplikasi berbentuk telepon yang mendukung penjualan, pemasaran, dan layanan lainnya yang berkaitan dengan proses bisnis CRM. Aplikasi ini mengimplementasikan fungsi-fungsi telemarketing, telesales, dan teleservices; Sales force automation yang mendukung upaya penjualan yang kompetitif, mengatur peran-peran penting, prospek, dan pelanggan melalui jalur penjualan yang sebenarnya; Field service automation yang mendukung usaha layanan pelanggan pada layanan bisnis sesuai dengan areanya. Aplikasi ini mengelola permintaan dari layanan pelanggan, melayani pemesanan, kontrak, penjadwalan, dan telepon serta menyediakan perencanaan, penjadwalan, pengiriman, dan laporan dari perwakilan layanan lapangan untuk layanan telepon.

\section{Analytical CRM}

Tujuan utamanya adalah mengelola data pelanggan dengan tepat sehingga perusahaan atau organisasi dapat selalu mengetahui apa yang diinginkan oleh pelanggan. Disini dapat dilihat tingkat kesetiaan pelanggan dan berapa pelanggan yang masih berada dalam data customer retention. Data diproses dari data warehouse yang menghasilkan laporan untuk menunjukan informasi tersebut. Analisis data pada operational CRM dengan memanfaatkan tools dan softwares ini dapat memberikan pemahaman yang lebih baik tentang perilaku pelanggan individu ataupun kelompok. Dengan aplikasi ini kita dapat menganalisis kinerja, efisiensi, dan efektivitas dari aplikasi operational CRM. 


\section{Collaborative CRM}

Tujuan utamanya adalah untuk memberikan dorongan dan mengarah pada pencapaian kesetiaan pelanggan ke pelanggan-pelanggan lain yang masih belum berada di tingkat "setia“. Aplikasi ini menjadi tempat mengadakan kontak dan interaksi antara pelanggan yang tersebar dimanamana dengan organisasi tersebut. Aplikasi kolaborasi ini meliputi e-mail, personalize publishing, $e$ communities, dan aplikasi lainnya yang dirancang untuk interaksi antara pelanggan dan organisasi.

\section{METODE}

Metode yang digunakan pada pembuatan tulisan ini adalah metode analisis dan perancangan sistem. Metode analisis dimulai dari melakukan pengumpulan data-data, baik melalui survei maupun wawancara langsung. Berdasarkan data-data yang terkumpul serta didasarkan pada studi pustaka dilakukan analisis industri untuk mengetahui posisi perusahaan saat ini. Sedangkan untuk melakukan perancangan sistem berdasarkan pada konsep Object Oriented Analysis and Design.

Berdasarkan hasil wawancara dan pengamatan terhadap proses bisnis yang terjadi pada perusahaan PT Terang Dunia Internusa, dapat diidentifikasikan beberapa permasalahan, diantaranya sebagai berikut: proses penyampaian informasi dari perusahaan kepada para pelanggan-nya dan sebaliknya, sangat tidak efisien dalam hal penggunaan waktu dan biaya; Sulitnya mempertahankan loyalitas dari para pelanggan mengingat banyaknya bermunculan perusahaan-perusahaan baru yang menjadi pesaing dari perusahaan PT Terang Dunia Internusa; Dalam proses bisnisnya, penghubung antara perusahaan dengan para pelanggan adalah melalui salesman. Hal ini memang cukup efektif bagi perusahaan dalam mencapai target penyebaran informasi, namun seiring dengan berjalannya waktu, pelanggan dari perusahaan juga akan semakin bertambah. Maka akan dibutuhkan penambahan tenaga kerja yang nantinya akan memperbesar biaya operasional; Apabila para pelanggan ingin menyampaikan masukan, seperti saran atau kritik ke pihak perusahaan, maka hal ini disampaikan kepada bagian salesman karena salesman merupakan penghubung perusahaan dengan para pelanggan. Namun, hal ini sangat tidak efektif karena kemungkinan salesman akan lupa untuk menyampaikannya karena tugas utama dari salesman adalah mencari order (pesanan). Jadi hal-hal kecil seperti ini rentan sekali tidak disampaikan; Kadang kala apabila perusahaan ingin melaksanakan suatu event yang melibatkan para pelanggan untuk ikut berpartisipasi, perusahaan sering mengalami kesulitan dalam menghubungi para pelanggan tersebut karena mungkin alamat atau nomor telepon nya telah berubah. Data-data pelanggan yang up to date biasanya disimpan oleh salesman. Oleh karena itu, hal seperti ini akan sangat menyulitkan pihak perusahaan; Sulitnya para pelanggan untuk mengajukan pertanyaanpertanyaan baik yang bersifat umum maupun khusus kepada pihak perusahaan seputar proses bisnis yang terjadi karena tidak adanya bagian khusus yang menangani hal tersebut; Seringkali staff produksi mengalami kesulitan dalam mencari informasi berkenaan dengan trend yang berkembang di dalam masyarakat.

\section{Analisis Industri}

Berdasarkan hasil wawancara dan pengamatan, dilakukan analisis industri yang didasarkan pada model lima kekuatan Porter. Berikut kondisi yang saat ini dihadapi oleh perusahaan PT Terang Dunia Internusa :

\section{Persaingan dalam industri (Rivalry in Industry)}

Sepeda sebagai alat transportasi yang hemat biaya, juga merupakan alat olahraga yang cukup praktis. Pada saat ini, dimana kondisi ekonomi masyarakat kita sedang mengalami krisis, maka sepeda 
dapat dijadikan sebagai alat transportasi yang cukup ekonomis. Hal ini merupakan peluang bisnis yang cukup menguntungkan dalam industri perdagangan. Oleh karena itu, industri sepeda dapat tetap berkembang di tengah-tengah berkembangnya industri kendaraan bermesin.

PT Terang Dunia sebagai salah satu industri yang bergerak dalam bidang produksi dan distribusi sepeda dan sparepart yang bermerek United telah lama menjadi bagian yang penting dalam dunia industri sepeda. Keunggulan perusahaan PT Terang Dunia Internusa dibandingkan dengan perusahaan pesaingnya adalah : Memiliki brand image yang cukup kuat karena telah lama menggeluti bidang industri sepeda; Kualitas produknya terjamin dibuktikan dengan diperolehnya pengakuan ISO 9001:2000 pada tahun 2003; Selalu melakukan inovasi produk; Memiliki jaringan distribusi yang cukup luas; Pelayanan servis yang cukup baik kepada para pelanggan-nya dan pengalaman dalam dunia industri yang cukup matang.

Keunggulan dari perusahaan PT Terang Dunia Internusa ini, merupakan faktor yang membuatnya dapat tetap bertahan dalam pangsa pasar. Walaupun memang diakui, produk yang ditawarkan tidak memiliki keunggulan dalam segi harga. Karena harga produk yang ditawarkan jauh lebih tinggi dari harga pada umumnya. Namun, dengan kualitas dan inovasi yang terus-menerus meningkat dapat menutupi kelemahannya tersebut. Selain itu, sasaran utama dari perusahaan ini adalah masyarakat dengan penghasilan menengah ke atas yang lebih mementingkan kualitas daripada harga.

Konsep bisnis yang dilakukan oleh perusahaan PT Terang Dunia Internusa ini, membuat para pesaing berusaha memanfaatkan kelemahan dari perusahaan, yaitu dari segi harga. Para pesaing berusaha membuat produk yang hampir menyamai produk dari PT Terang Dunia Internusa dengan penawaran harga yang tentunya lebih rendah dari yang ditawarkan perusahaan. Hal ini akan menjadi ancaman yang cukup berarti bagi perusahaan PT Terang Dunia Internusa untuk dapat berkembang. Biasanya untuk mengatasi hal tersebut, perusahaan melakukan inovasi produk yang berkala dengan tetap mengutamakan segi kualitas karena produk yang ditawarkan oleh para pesaing biasanya lebih rendah kualitasnya dibandingkan yang ditawarkan perusahaan. Jadi hal ini merupakan nilai unggul bagi perusahaan.

\section{Kekuatan Menawar dari Pembeli/Pelanggan (Bargaining Power of Customer)}

Pelanggan utama dari perusahaan PT Terang Dunia Internusa ini kebanyakan adalah para dealer, toko sepeda, toko alat olah raga, dll. Mereka merupakan penyalur produk perusahaan ke konsumen akhir. Kebanyakan dari mereka membeli produk perusahaan dalam jumlah yang cukup besar dengan tujuan untuk dipasarkan kembali ke konsumen akhir. Oleh karena itu, mereka selalu berusaha mendapatkan harga yang menguntungkan dan membeli secara selektif agar mereka dapat memperoleh keuntungan dari barang yang dipasarkannya tersebut. Apabila laba yang diperoleh cenderung lebih kecil, maka kemungkinan, mereka akan beralih memasarkan produk dari perusahaan lain yang sekiranya dapat mendatangkan keuntungan yang lebih besar. Hal ini merupakan ancaman bagi perusahaan PT Terang Dunia Internusa untuk dapat berkembang. Walaupun perusahaan terus berusaha untuk menjalin hubungan baik dengan para dealer, misalnya dengan memberikan fasilitas pembayaran secara kredit, memberikan bonus-bonus, mengadakan acara tahunan bagi para dealer. Namun, apabila para penyalur tersebut merasa produk yang dipasarkan tidak lagi bisa mendatangkan keuntungan bagi mereka, maka kemungkinan besar mereka akan beralih ke perusahaan lain yang dapat mendatangkan keuntungan yang lebih besar bagi mereka. Jadi dapat disimpulkan bahwa kekuatan pembeli sangat berpengaruh terhadap perusahaan.

\section{Kekuatan Menawar dari Pemasok (Bargaining Power of Supplier)}

Perusahaan PT Terang Dunia Internusa merupakan perusahaan yang memproduksi dan mendistribusikan sepeda dan sparepart yang bermerek UNITED. Keberadaan supplier (pemasok) 
hanya berperan sebagai pemasok barang pelengkap saja bagi produk-produk yang dijual. Oleh karena itu, kekuatan pemasok tidak terlalu mempengaruhi proses bisnis yang berlangsung. Selain itu, biaya pengalihan tidak terlalu tinggi. Jadi perusahaan dapat berganti pemasok dengan mudah tanpa terikat oleh faktor apapun. Bahkan keberadaan pemasok tidak terlalu berarti karena perusahaan dapat memproduksi sendiri peralatan yang dibutuhkan.

Perusahan bisa dikategorikan merupakan pelanggan penting bagi para pemasok, karena perusahaan PT Terang Dunia Internusa produknya telah dikenal oleh pasar. Jadi, apabila pemasok memasok barang ke perusahaan, maka barang yang dipasok tersebut akan dikenal juga oleh konsumen. Bahkan dapat menaikan brand image dari barang yang dipasok tersebut.

\section{Ancaman Pendatang Baru dalam Industri ( New Entrants Threat)}

Hambatan yang dihadapi untuk masuk dalam industri ini cukup tinggi karena membutuhkan modal yang relatif cukup besar, serta kemampuan dalam melakukan inovasi produk dan melakukan pemasaran produk. Sehingga dengan begitu, para pelanggan tertarik dengan produk yang dipasarkan. Selain itu, perusahaan harus memiliki nilai tambah tersendiri yang membedakan perusahaannya dengan perusahaan yang ada sekarang ini. Kebanyakan dari para pendatang baru tersebut, melakukan inovasi dalam segi harga. Mereka cenderung mengeluarkan produk dengan harga yang lebih rendah dengan tujuan menarik para pelanggan. Sedangkan daya tarik untuk para dealer, mereka memberikan fasilitas pembayaran credit dengan jangka waktu pembayaran yang lebih lama daripada yang ditawarkan oleh perusahaan PT Terang Dunia Internusa.

Para pendatang baru ini cukup memberikan competitive yang sangat ketat dalam dunia bisnis. Hal ini sangat mempengaruhi perusahaan dalam mengembangkan bisnisnya. Oleh karena itu, ancaman dari para pendatang baru sangat berpengaruh bagi eksistensi perusahaan.

\section{Ketersediaan Barang Substitusi (Substitute Product)}

Produk pengganti yang dapat mengganti fungsi produk perusahaan PT Terang Dunia Internusa saat ini sangat banyak beredar, diantaranya kendaraan bermesin, seperti skutter listrik dan motor. Hal ini memiliki pengaruh yang sangat berarti bagi perusahaan karena dapat mengancam bisnis perusahaan karena para konsumen cenderung menyukai kendaraan bermesin yang dirasa lebih praktis dibandingkan sepeda. Namun, bagi orang-orang yang memiliki hobi tersendiri, seperti balap sepeda, fun bike, dll pastilah masih membutuhkan keberadaan sepeda. Selain itu untuk menganalisis industri dari PT Terang Dunia Internusa, dilakukan pula analisis SWOT (Strength Weakness Opportunity Threat) agar dapat mengidentifikasi faktor-faktor internal dan eksternal yang sekiranya dapat mempengaruhi eksistensi perusahaan. Faktor internal meliputi kekuatan dan kelemahan yang dimiliki oleh perusahaan. Sedangkan faktor eksternal meliputi peluang yang ada dalam pasar dan ancaman yang datang dari para pesaing. Dari tiap faktor-faktor tersebut nantinya akan dibandingkan satu persatu dengan menggunakan metode Pairwise, kira-kira faktor mana saja yang paling berpengaruh.

Berikut ini adalah matriks SWOT dari perusahaan PT Terang Dunia Internusa: 


\begin{tabular}{|c|c|c|}
\hline Faktor Internal & Strength (S) & Weakness (W) \\
\hline Faktor Eksternal & 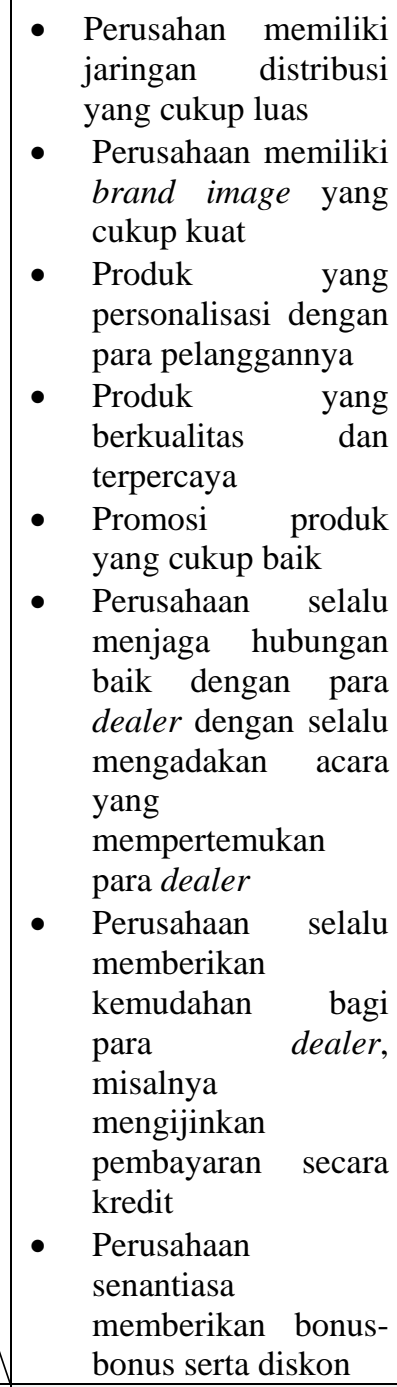 & $\begin{array}{l}\text { - Sistem yang kurang bisa } \\
\text { mengakomodir informasi } \\
\text { mengenai dealer/pelanggan. } \\
\text { - Harga produk yang cukup mahal, } \\
\text { jika dibandingkan dengan harga } \\
\text { sepeda pada umumnya }\end{array}$ \\
\hline $\begin{array}{l}\text { Opportunities (O) } \\
\text { - Pangsa pasar di Indonesia } \\
\text { cukup luas } \\
\text { - Sepeda selain dapat dijadikan } \\
\text { alat transportasi, juga dapat } \\
\text { dijadikan sarana olah raga } \\
\text { - Kepuasan dealer terhadap } \\
\text { mutu dan pelayanan dari } \\
\text { perusahaan } \\
\text { - Dicanangkan gerakan Go } \\
\text { Green. }\end{array}$ & 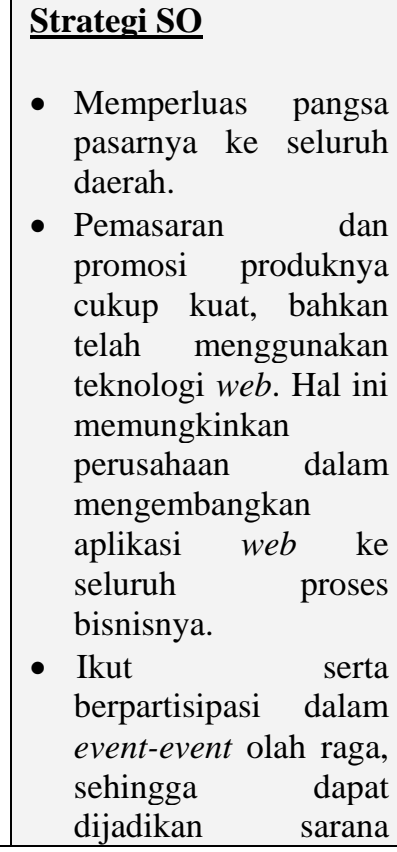 & $\begin{array}{l}\text { Strategi WO } \\
\text { - Menciptakan produk dengan } \\
\text { kualitas yang dapat memuaskan } \\
\text { pelanggan, sehingga dapat unggul } \\
\text { dari segi kualitas walaupun harga } \\
\text { cukup mahal } \\
\text { - Membuat suatu aplikasi website } \\
\text { yang dapat dijadikan penghubung } \\
\text { antara perusahaan dengan para } \\
\text { dealer-nya. Sehingga dapat } \\
\text { memudahkan perusahaan dalam } \\
\text { mencari informasi berkenaan } \\
\text { dengan para dealer-nya }\end{array}$ \\
\hline
\end{tabular}




\begin{tabular}{|c|c|c|}
\hline & 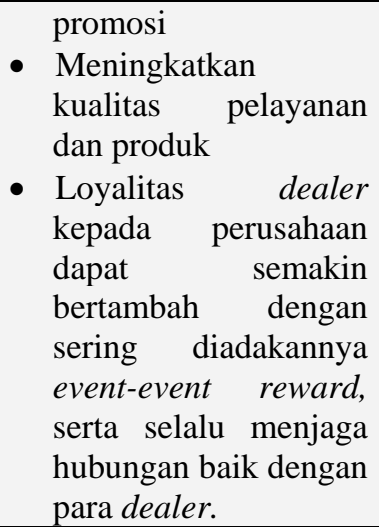 & \\
\hline $\begin{array}{l}\text { Threats (T) } \\
\text { - Persaingan bisnis yang ketat, } \\
\text { banyak produk dari luar } \\
\text { masuk ke Indonesia } \\
\text { - Masyarakat cenderung } \\
\text { memilih kendaraan bermesin, } \\
\text { dibandingkan sepeda } \\
\text { - Kondisi perekonomian di } \\
\text { Indonesia yang membuat para } \\
\text { pelanggan lebih } \\
\text { mementingkan harga murah } \\
\text { dibandingkan kualitas barang. } \\
\text { - Kemajuan teknologi informasi } \\
\text { dapat menjadi ancaman bagi } \\
\text { perusahaan dalam } \\
\text { pelaksanaan proses bisnisnya }\end{array}$ & 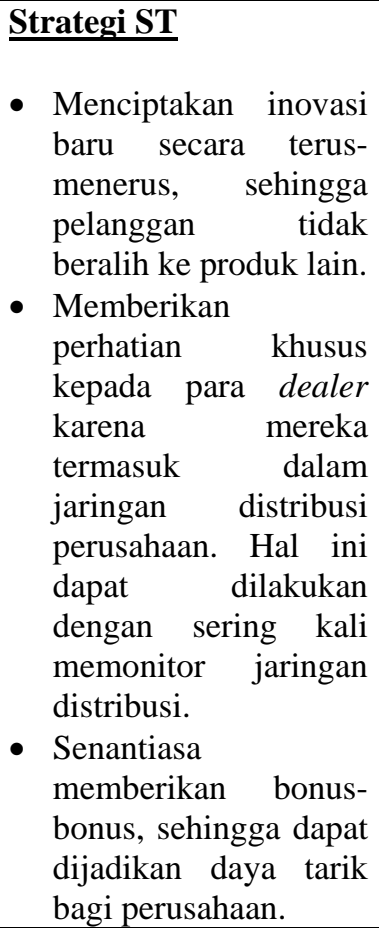 & $\begin{array}{l}\text { Strategi WT } \\
\text { - Memfokuskan perusahaan pada } \\
\text { kualitas produk dan pelayanan } \\
\text { terhadap dealer, sehingga dealer } \\
\text { tidak beralih ke perusahaan lain. }\end{array}$ \\
\hline
\end{tabular}

Gambar 3 Matriks SWOT dari perusahaan PT Terang Dunia Internusa

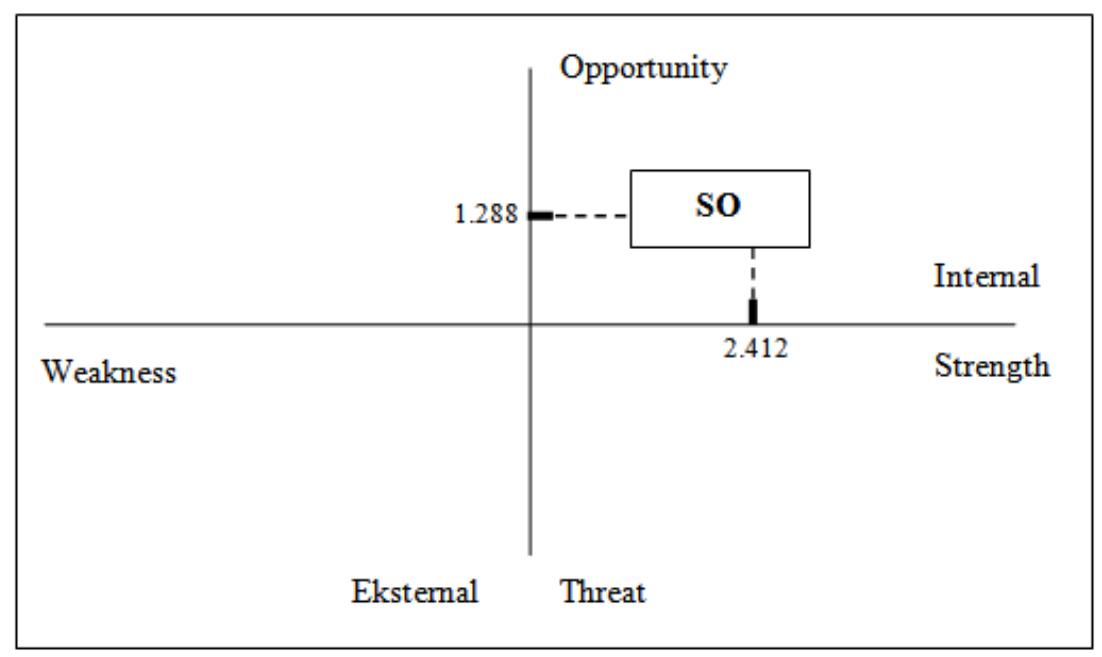

Gambar 4 Diagram Analisis SWOT PT Terang Dunia Internusa 
Berdasarkan hasil analisis SWOT pada hasil kuisioner yang dikumpulkan, maka PT Terang Dunia Internusa berada pada posisi strategi bisnis SO (Strength-Opportunity). Hal ini merupakan situasi bisnis yang sangat menguntungkan bagi perusahaan, dimana perusahaan PT Terang Dunia Internusa memiliki kekuatan yang cukup dalam menghadapi segala ancaman dengan memanfaatkan peluang yang ada.

Atas dasar hal tersebut, maka perusahaan dapat menjalankan beberapa strategi berikut guna mempertahankan posisi yang telah dicapai. Strategi SO tersebut adalah : Memperluas pangsa pasarnya ke seluruh daerah; Meningkatkan kualitas barang serta pelayanan ke para dealer; Ikut serta berpartisipasi dalam event-event olah raga, sehingga dapat dijadikan sarana promosi; Mengembangkan aplikasi web ke seluruh proses bisnis perusahaan, guna meningkatkan pelayanan kepada para dealer. Hal ini dapat dilakukan dengan membangun suatu aplikasi website e-CRM yang dapat menjadi penghubung perusahaan dengan para dealernya.

\section{HASIL DAN PEMBAHASAN}

\section{Analisis \& Perancangan Sistem yang Diusulkan}

Rancangan sistem yang diajukan bagi perusahaan, yaitu suatu solusi bisnis berbasiskan CRM yang nantinya akan menjadi penghubung antara perusahaan dengan para pelanggan. Dalam aplikasi tersebut terdapat modul-modul yang dapat membantu perusahaan dalam mengatasi permasalahan yang dihadapinya. Adapun rancangan sistem yang diusulkan berdasarkan masalah yang dihadapi perusahaan adalah sebagai berikut : Berdasarkan analisis SWOT, ditemukan permasalahan, yaitu perusahaan sulit memperoleh informasi mengenai para pelanggan dan untuk mencari informasi tersebut memerlukan biaya yang cukup mahal dan waktu yang lama. Untuk mengatasi permasalahan tersebut, maka pada aplikasi dibuat suatu modul yang berisi profile dari para pelanggan. Pada modul tersebut, masing-masing pelanggan dapat dengan mudah melihat data pribadi mereka, mengubah sendiri data pribadinya masing-masing apabila ternyata data-nya telah berubah. Jadi dengan begitu, perusahaan tidak usah repot-repot untuk mencari data pelanggan tersebut; Berdasarkan hasil wawancara pada pihak perusahaan, diperoleh informasi bahwa selama ini apabila perusahaan ingin mengeluarkan produk baru atau telah mengeluarkan produk baru, maka perusahaan akan melakukan survei ke lapangan guna mendapatkan informasi feedback atas inovasi yang dilakukan perusahaan. Biasanya pihak perusahaan akan membentuk tim survei lapangan guna mendapatkan informasi tersebut. Hal ini sangatlah tidak efisien, mengingat pelanggan dari perusahaan tersebar di seluruh daerah, maka akan diperlukan biaya yang sangat besar sekali. Oleh karena itu, pada rancangan aplikasi yang diajukan, terdapat modul kuisioner. Sehingga kapan pun perusahaan ingin melakukan survei, dapat dilakukan dengan mudah dan respon dari para pelanggan-pun dapat diperoleh dengan lebih cepat dibandingkan dengan menggunakan cara sebelumnya; Berdasarkan hasil wawancara dengan para pelanggan, diperoleh hasil bahwa selama ini pelanggan mengalami kesulitan dalam mengajukan pertanyaan seputar proses bisnis perusahaan serta dalam hal pengajuan saran dan kritik terhadap perusahaan. Kebanyakan pelanggan mengalami kebingungan dalam menyampaikan kepada siapa tepatnya pengajuan pertanyaan, saran, dan kritik tersebut diajukan.

Sekalipun ada biasanya pelanggan menyampaikan kepada orang yang selama ini berinteraksi langsung dengan para pelanggan, yaitu salesman ataupun sales admin perusahaan. Namun, penyampaian melalui perantara tersebut tidak memberikan jaminan bahwa informasi dari para pelanggan tersebut tersampaikan dengan baik karena tugas utama dari mereka bukanlah mengurusi hal tersebut. Jadi, kemungkinan informasi tersebut tidak tersampaikan dengan baik kepada pihak yang tepat. Oleh karena itu pada rancangan sistem yang baru terdapat modul pertanyaan, FAQ, dan saran \& kritik. Modul tersebut dapat membantu para pelanggan dalam mendapatkan informasi sekaligus 
menyampaikan segala informasi kepada perusahaan guna membantu perusahaan untuk menjadi lebih baik lagi ke depannya; Berdasarkan hasil wawancara dengan pihak perusahaan, diperoleh informasi bahwa perusahaan sering mengadakan event-event tertentu yang mengikutsertakan para pelanggan untuk berpartisipasi. Untuk mengundang para pelanggan dalam event yang diadakan perusahaan tersebut pastinya diperlukan biaya dan waktu yang cukup banyak. Dengan begitu, pada aplikasi dibuat suatu modul mengenai pengumuman (general announcement). Dalam modul tersebut, para pelanggan dapat melihat semua informasi yang disampaikan perusahaan; Pada sistem yang berjalan, setiap pelanggan yang akan melakukan transaksi pembelian, sebelumnya akan dicek terlebih dahulu status kredit dari pelanggan tersebut oleh bagian sales admin perusahaan. Pelanggan tersebut akan dicek apakah status kredit-nya telah mencapai limit atau belum. Jika telah mencapai limit, maka pelanggan tidak bisa melakukan transaksi pembelian sampai pelanggan tersebut melunasi kredit-nya. Sedangkan apabila pelanggan tersebut tidak memiliki kredit atau kredit-nya belum mencapai limit, maka dapat melakukan transaksi. Oleh karena itu, pada sistem yang baru dibuat suatu modul yang meringankan tugas dari sales admin. Modul tersebut digunakan untuk menampilkan status kredit dari pelanggan tersebut. Sehingga pelanggan dapat melihat sendiri status kredit-nya. Bahkan pelanggan tersebut dapat melihat sendiri seluruh history transaksi yang pernah dilakukan, mulai dari sales order, back order, klaim, dan retur; Selain itu dalam modul aplikasi yang diajukan terdapat modul Point, dimana apabila perusahaan sedang mengadakan event reward, yaitu pengumpulan poin berhadiah bagi para pelanggan, maka para pelanggan dapat melihat sendiri jumlah poin yang telah diperolehnya melalui modul tersebut. Hal ini dapat membantu perusahaan dalam hal meningkatkan loyalitas dari para pelanggan; Selain itu, pada aplikasi juga terdapat modul promo, dimana para pelanggan dapat memasukkan alamat email-nya apabila ingin mendapatkan informasi lebih mengenai keuntungan dan kekurangan menjadi pelanggan dari perusahaan PT Terang Dunia Internusa.

\section{Arsitektur CRM}

Bentuk arsitektur CRM yang diusulkan perlu memenuhi aspek-aspek yang mendukung perusahaan dalam menciptakan dan meningkatkan hubungan dengan para pelanggannya. Aspek itu adalah :

\section{Mendapatkan konsumen baru (Acquire)}

Untuk memperoleh pelanggan baru, pada website terdapat modul register, promosi, general announcement, FAQ bagi para pelanggan baru. Pada modul promosi, perusahaan melakukan aktifitas pemasaran kepada para pelanggan baru, guna menarik minat mereka untuk bergabung dalam memasarkan produk perusahaan PT Terang Dunia Internusa. Hal ini dilakukan dengan cara meminta pengunjung website untuk memasukkan alamat email-nya. Sehingga nantinya perusahaan akan mengirimkan promosi-promosi perusahaan melalui alamat email tersebut; Setelah mereka tertarik untuk bergabung, para pelanggan dapat memilih menu register yang berfungsi untuk mendaftarkan diri mereka untuk bergabung dengan perusahaan. Setelah mereka register, pihak perusahaan akan menghubungi mereka dalam waktu 1 x 24 jam; Pada modul general announcement, para pelanggan dapat melihat event-event yang diadakan perusahaan. Hal ini dapat menarik minat para pelanggan untuk ikut berpartisipasi dalam event tersebut. Keikutsertaan mereka akan menjadi peluang bagi perusahaan untuk menawarkan produk perusahaan; Pada modul FAQ, para pelanggan dapat melihat semua list pertanyaan yang sering diajukan berserta jawabannya. Dari semua pertanyaan tersebut, para pelanggan dapat memperkirakan apa saja keuntungan dan kerugian yang mungkin mereka dapatkan jika bergabung dengan perusahaan. Jadi dengan begitu, modul FAQ ini menjadi faktor pendukung dalam menarik pelanggan baru. Meningkatkan kemampuan untuk menghasilkan keuntungan dari pelanggan yang telah ada (Enhance). Pada website yang diusulkan terdapat modul Transaction, My History dan Point. Pada modul Transaction ini, para pelanggan dapat melakukan transaksi dengan lebih mudah dan cepat, bahkan dapat melakukan transaksi dimana saja dan kapan pun mereka inginkan. Pada menu Transaction ini, para pelanggan dapat melakukan pemesanan (order), pembatalan pemesanan (back order), mengajukan klaim, dan melakukan retur barang; Selain itu, 
disediakan juga modul history transaction, dimana pada modul ini para pelanggan dapat melihat transaksi-transaksi yang pernah dilakukannya selama ini pada perusahaan, mulai dari pemesanan (order), pembatalan pemesanan (back order), mengajukan klaim, dan melakukan retur barang; Pada menu Point, para pelanggan dapat melihat perolehan poin yang dicapai pelanggan tersebut. Biasanya dalam rangka meningkatkan loyalitas dari para pelanggan, perusahaan sering mengadakan event-event reward yang memberikan hadiah kepada para pelanggan atas pengumpulan poin tertentu berdasarkan pada besarnya transaksi yang dilakukannya. Hal ini dapat menarik minat para pelanggan untuk membeli produk perusahaan lebih banyak lagi, guna mendapatkan poin-poin tersebut.

\section{Mempertahankan konsumen yang ada (retain)}

Pada website yang diusulkan terdapat modul Product, Critical \& Sugestion, Question, Private Announcement, Questionnaire, Forum dan Buletin.

Pada modul Product ini pelanggan dapat melihat semua produk-produk yang ditawarkan perusahaan, baik produk baru, best seller maupun produk lama. Sehingga informasi pelanggan akan produk perusahaan dapat tetap ter-update; Pada modul Critical \& Sugestion, para pelanggan dapat mengajukan kritik dan saran kepada pihak perusahaan, baik yang berkenaan dengan pemasaran, penjualan, produk, pelayanan dll. Yang nantinya segala informasi tersebut akan ditampung oleh pihak perusahaan sebagai bahan pertimbangan dan acuan bagi pihak perusahaan untuk lebih berkembang. Selain itu, informasi yang diperoleh dapat membantu perusahaan dalam mengidentifikasi segala kekurangan yang terdapat pada perusahaan, yang dapat memberikan ancaman bagi perusahaan kehilangan pelanggan yang selama ini telah menjadi aset perusahaan; Pada modul Private Announcement, para pelanggan akan memperoleh informasi khusus dari pihak perusahaan, contohnya reminder jatuh tempo piutang, undangan atas event tertentu yang diadakan pihak perusahaan, pemberitahuan mengenai list harga produk perusahaan, produk baru yang dikeluarkan perusahaan, dll. Dengan begitu, para pelanggan akan merasa diperhatikan oleh pihak perusahaan; Pada modul Question, para pelanggan dapat mengajukan pertanyaan-pertanyaan seputar proses bisnis yang selama ini dilakukan kepada pihak perusahaan. Pertanyaan ini akan dijawab oleh pihak perusahaan dalam waktu 1 x 24 jam; Pada modul Questionnaire, perusahaan dapat melakukan survei mengenai segala informasi yang ingin diketahui oleh perusahaan. Dengan begitu, perusahaan dapat memperoleh feedback dari pihak pelanggan berkenaan dengan aktifitas survei yang dilakukan oleh perusahaan. Dari hasil survei tersebut, pihak perusahaan dapat memperoleh informasi mengenai apa yang menjadi kekurangan dan ancaman dari aktifitas yang dilakukan perusahaan; Pada modul forum dan buletin ini, para pelanggan dapat melihat segala informasi yang disampaikan oleh para pelanggan yang tergabung di dalam website. Selain itu, forum juga dapat digunakan sebagai sarana untuk bertukar pikiran apabila terjadi suatu permasalahan.

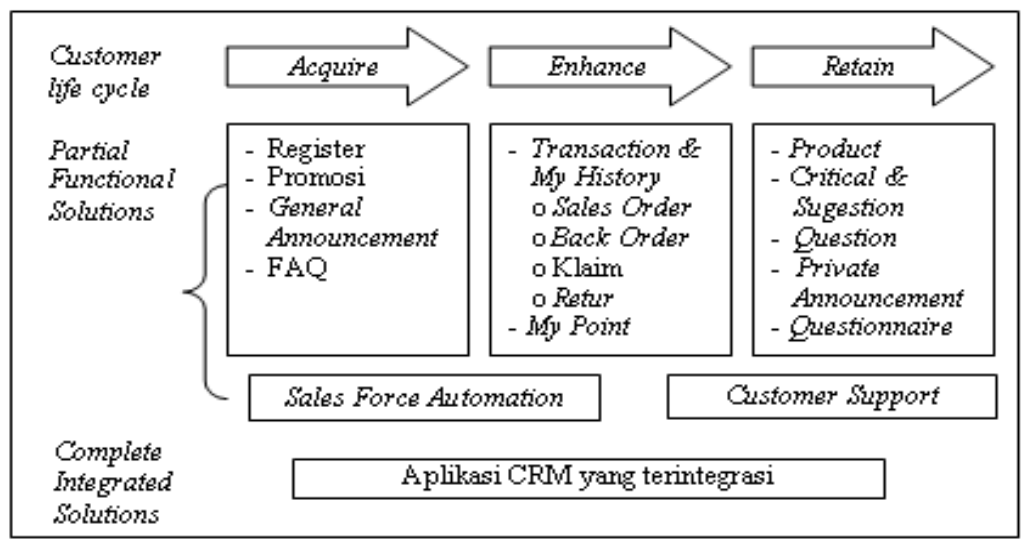

Gambar 5 Arsitektur CRM 


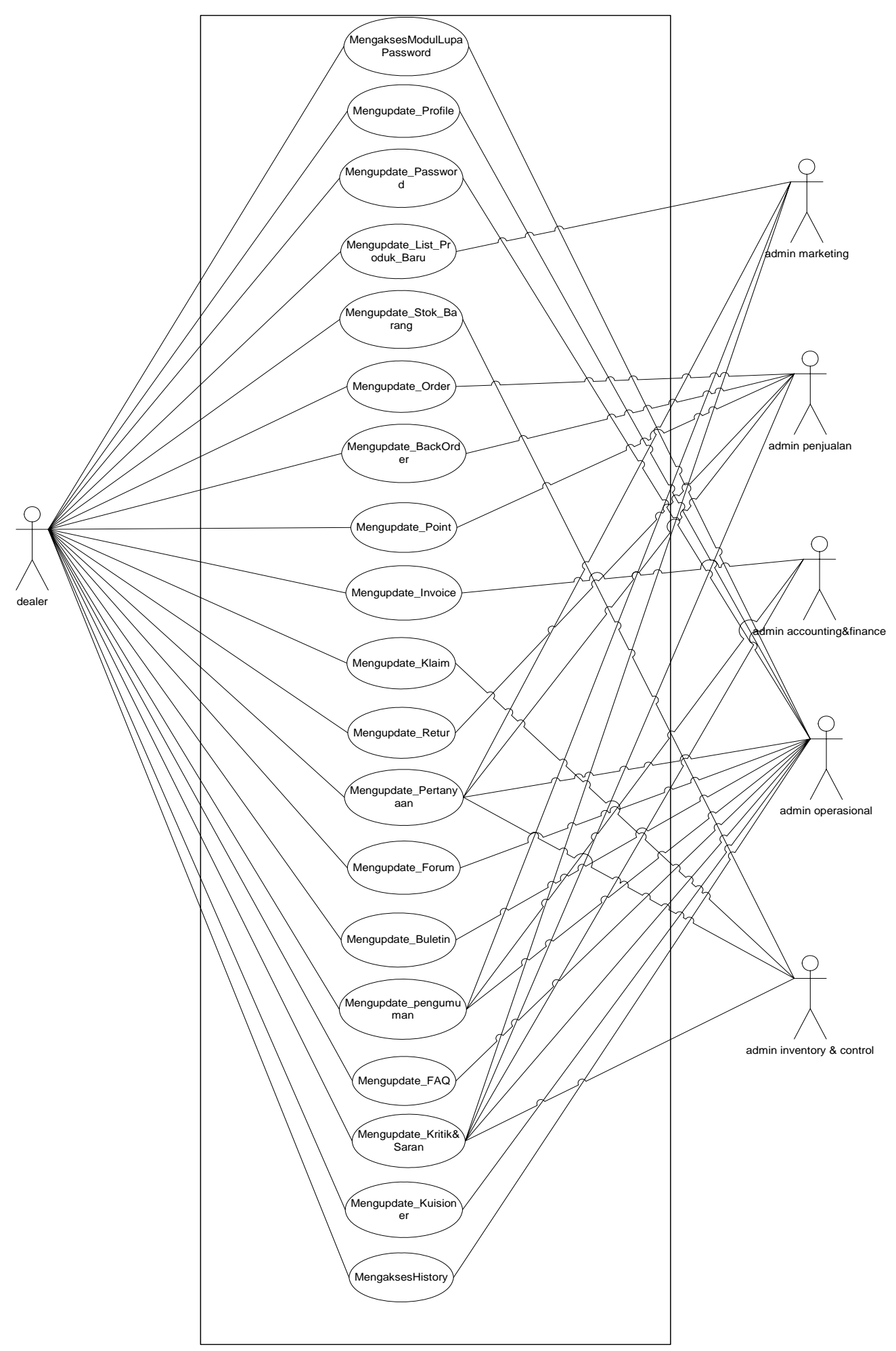

Gambar 6 Use Case Diagram PT Terang Dunia Internusa

\section{SIMPULAN}

Setelah dilakukan analisis dan perancangan terhadap sistem pada perusahaan PT Terang Dunia Internusa, maka dapat ditarik beberapa simpulan, yaitu: Dalam pelaksanaan proses bisnisnya, 
informasi-informasi mengenai para pelanggan menjadi bagian terpenting bagi perusahaan. Sering kali perusahaan melakukan survei lapangan guna mendapatkan informasi tersebut. Namun melalui aplikasi yang diusulkan, perusahaan tidak perlu lagi membuat tim khusus untuk melakukan survei ke lapangan karena dalam aplikasi tersebut, para pelanggan dapat menyampaikan feed back kepada pihak perusahaan, baik yang berupa kritik \& saran, pertanyaan, serta apabila perusahaan ingin melakukan kuisioner maka dapat langsung direspon dengan cepat oleh para pelanggan; Melalui aplikasi yang diusulkan, proses transaksi akan menjadi lebih mudah. Dimana sebelumnya, apabila pelanggan ingin memesan barang, maka harus melalui salesman yang mendatangi pelanggan atau datang langsung ke perusahaan. Tetapi melalui aplikasi yang diajukan, para pelanggan dapat melakukan transaksi kapan saja dan dimana saja; Aplikasi yang diusulkan ini akan menjadi penghubung antara perusahaan dengan para pelanggan-nya. Sehingga dengan begitu, perusahaan dapat dengan mudah memonitor para pelanggan-nya; Pada aplikasi yang diajukan, menerapkan konsep Customer Touching Application, dimana para pelanggan dituntut untuk dapat melayani dirinya sendiri. Mulai dari mengajukan pesanan, back order, claim, return, meng-update data diri, dll; Aliran informasi dari perusahaan ke pelanggan menjadi lebih efisien dan efektif. Contohnya penyampaian informasi perolehan poin, status transaksi, informasi penyelengaraan kegiatan-kegiatan perusahaan dan lain sebagainya.

Pada sistem yang diajukan masih memiliki beberapa kekurangan-kekurangan, sehingga untuk implementasi ke depannya perusahan harus memperhatikan hal-hal berikut : Perlu dibentuknya divisi khusus yang mengurus dan me-maintainance sistem. Dengan begitu segala feedback yang diajukan oleh pihak pelanggan dapat tersalurkan dengan baik; Pada aplikasi yang diajukan belum adanya sekuritas dari jaringan, oleh karena itu perlu pengembangan lebih lanjut apabila perusahaan ingin menerapkan aplikasi yang diajukan pada sistem perusahaan; Aplikasi yang diajukan belum secara optimal memenuhi kebutuhan back end karena aplikasi yang dibuat ini hanya menampilkan tahap operasional CRM, sedangkan apabila perusahaan ingin benar-benar menerapkan konsep CRM, maka diperlukan adanya tahap analytical CRM yang memuat seluruh informasi mengenai para pelanggan yang berfungsi sebagai bahan masukan dan pertimbangan bagi perusahaan ke depannya. Oleh karena itu, diharapkan ke depannya perusahaan dapat menambahkan modul tersebut ke dalam aplikasi yang diajukan.

\section{DAFTAR PUSTAKA}

Kalakota, R., \& Robinson, M. (2001). E-Business 2.0: Roadmap for Success. United States of America: Addison-Wesley

Kincaid, J. W. (2003). Customer Relationship Management: getting it right!. New Jersey: PrenticeHall, Inc

Seybold, P. (2002). An Executive Guide to CRM. Boston, MA: PS Group 